\title{
Az autológ idegtranszplantátumok helyett alkalmazott módszerek a kéz idegsérüléseinek helyreállításában
}

\author{
Bíró Vilmos dr.
}

Az autológ idegtranszplantátumokat a kézidegek defektussal járó sérüléseinél régóta alkalmazzák a klinikai gyakorlatban. A publikált végeredmények különösképpen a kevert (mozgató-érző) idegek helyreállítása során azonban korántsem bizonyultak kielégítőnek. Ezért került ez a kérdéskör a témával foglalkozó kutatók állandó figyelmébe, és irodalmi összegező közleményében a szerző is e témakör tanulmányozását és az összefüggések levonását tüzte ki célul. Az újabb vizsgálatok szerint a testazonos idegtranszplantátumok pótlása egyéb anyagokkal (idegvezető csövek, különböző allograftok [azonos speciesből nyert idegszövetek stb.]) jó végeredményeket mutattak kevert idegek esetében is, amennyiben a reszekált idegvégek közötti távolság nem haladta meg a $6 \mathrm{~mm}$-t és az ideg átmérője legfeljebb 3-7 mm között volt. A módszerek használata ennél nagyobb defektus, valamint idegátmérő felett rossz eredményeket mutatott fel. Így ezeknél az eseteknél továbbra is az optimális kezelési módszer az autológ idegátültetés maradt. Orv Hetil. 2017; 158(30): 1163-1167.

Kulcsszavak: kézidegek sérülései, idegdefektusok, autológ idegátültetés, idegtranszplantáció allografttal, idegvezető csövek

\section{Applied methods instead of autologous nerve transplantation in the reconstruction of nerve injuries on the hand}

For a long time in the clinical practice the autologous nerve transplants are used in reconstruction of the segmental defects of injured hand nerves. The published outcomes, especially in case of the motor and mixed (sensory and motor) nerves, however, were not satisfactory. Hence, it remained a problem and in the focus of research. The author aimed to study this topic and drawing conclusions in his literary review publication. According to the recent results, the replacement of the autologous nerve transplants with other materials (e.g. nerve conduits, various allografts, etc.) has shown good outcomes in mixed nerves too, if the distance of the resected nerve ends do not exceed $6 \mathrm{~mm}$ and the diameter of the nerves were not more than 3-7 $\mathrm{mm}$. The applications of these methods have shown poor results, if the defect and/or the nerve diameter were larger. So, in these cases the autologous nerve transplantation remains the optimal management in the future.

Keywords: nerve injuries in the hand, segmental defects of the nerves, autologous nerve transplantation, allograft transplantation, nerve conduit tubes

Bíró V. [Applied methods instead of autologous nerve transplantation in the reconstruction of nerve injuries on the hand]. Orv Hetil. 2017; 158(30): 1163-1167.

(Beérkezett: 2017. május 24.; elfogadva: 2017. június 15.)

Az Orvosi Hetilap alapításának 160. évében, a Szerkesztőség felkérésére készített tanulmány. 
A felső végtag sérüléseinek gyakori következménye a perifériás, elsősorban a kézen előforduló érző- és/vagy mozgatóidegek károsodása. A folytonosságát vesztett idegnél sebészi beavatkozásra van szükség, hogy a funkció többé-kevésbé helyreálljon: ha a sérült idegvégek a károsodott részeknek az ép fasciculusokig történő kimetszése után feszülés nélkül összeérinthetőek, idegvarratot készítenek a szakemberek. Amennyiben az ideg csak feszülés árán lenne egyesíthető, idegátültetésre lesz szükség. Az elmúlt évtizedekben nagymértékű fejlődésnek lehettünk tanúi az idegsérülések rekonstrukciós mútéteiben is: a nagyobb kézsebészeti centrumokban (így hazánkban is) általánossá vált az operációs mikroszkóp, a kifinomult mútéti technika, a speciális (10/0-11/0), atraumatikus varróanyagok és a szakszerü utókezelés alkalmazása. Nagyon fontos - talán a legfontosabb - tényező az idegsérülések mütéti kezelésére specializálódott kézsebész szakemberek tevékenysége. Ehhez hozzátartozik az e területen dolgozó kollégák mikrosebészeti alap- és továbbképzése, a személyi és tárgyi feltételek folyamatos megteremtése is, amely a még jobb funkcionális végeredmények elérését segíti elő. Mindezek következtében a korábban kedvezőtlen végeredmények javultak, azonban szomorú tény, hogy az idegvezetés teljes helyreállása rekonstrukciós beavatkozás után meglehetősen ritka és gyakran szövődik neuropathiás tünetekkel. Ilyen esetekben a beteg élethosszig tartó fogyatékossággal, fájdalommal és csökkent életminőséggel kénytelen élni. Kielégítő végeredményeket elsősorban a monofascicularis érzőidegeket érintő kisebb sérülések (neuropraxia, illetve axonotmesis) után figyeltek meg. Teljes idegátmetszés (neurotmesis) után ugyanakkor az idegszövet funkciójának helyreállása lényegesen kevesebb sikerrel kecsegtet; különösképpen, ha a sérülés helye és a végkészülék közötti távolság tetemes [1]. A helyreállított idegsérülések utáni funkcionális eredmények még kedvezőtlenebbek lehetnek, amikor a sérüléstől a helyreállító mütétig jelentős idő telik el - ahogyan ezt gyakran észleljük a klinikai gyakorlatban. A sérült distalis idegcsonk állományában (Waller-féle) degenerációs jelenségek jönnek létre és kifogástalanul elvégzett primer rekonstrukciós mútét után is az axonok regenerálódási képessége legfeljebb $1 \mathrm{~mm}$ lehet naponta. Így az idegsérülés magasságától függően jelentős idő telhet el, amíg az idegrostok elérik a végkészülékeket. Mozgatórostok esetében ilyenkor jelentős izomatrophiával számolhatunk [2].

Ami az autológ idegátültetések helyettesítésére alkalmazott (fóképpen kísérletes) eljárásokat illeti, a külföldi szakirodalomban számos publikáció lelhető fel; a számunkra jelentősnek számító hivatkozásokat a dolgozat Irodalom részében tüntettük fel. Külön ki kell emelnünk Rbia és Shin újabb tanulmányát [3], amely nagy részletességgel tárgyalja e kérdéskört, ennélfogva munkájukat alapvető közleménynek használtuk fel dolgozatunk megírásához. Hazai szerzők e kérdéssel foglalkozó összefoglaló tanulmányáról nincsen tudomásunk, azonban a té- makörrel érintőlegesen foglalkozó publikációkat munkánkban igyekeztünk feltüntetni [1, 2, 4-11].

A régóta alkalmazott („gold standard”) kezelési módszer a mozgató, illetve érző vagy a kevert (érző és mozgató) kézidegek perifériás szegmentális hiányának rekonstrukciójára sokáig egyedül a testazonos idegtranszplantációt végezték [12]. E technika hátrányai jól ismertek: az adóterületen kialakult panaszok és a rendelkezésre álló donoridegek korlátozott száma miatt. Ezenfelül a funkcionális végeredmények gyakran nem bizonyultak egyértelműen kedvezőnek, különösképpen kevert idegek esetében [13].

A sérült mozgató-, illetve a kevert idegek helyreállító mútétei során nagy kihívást jelent a proximalis és a distalis csonkok fasciculusainak pontos identifikálása és egyesítése. Brushart [14-16] kísérletes vizsgálataiban igazolta, hogy a motoros és a szenzoros idegrostok lefutása az idegen belül különböző, és a tisztán érzőidegek helyreállítására alkalmazott ideggraftok regenerációja jóval tökéletesebben megy végbe, mint a mozgatóké.

Az idegtranszplantáció alternatívájaként a különböző anyagból készített idegvezetó csöveket már az 1980-as évek második felétől alkalmazták. Ezek fizikális burokként szerepeltek, hogy elválasztva a sérült ideget a környező szövetektől, a zárt kamrában lehetôvé tegyék az idegvégekből felszabaduló neurotrofikus faktorok koncentrált kiválasztását és hatásukat az axonok növekedésére [17].

Az első, l-es típusú kollagénből készült idegvezető csövet az Amerikai Egyesült Államokban alkalmazták NeuraGen gyári néven [18]. Később két másik, szintetikus alapanyagú cső is kereskedelmi forgalomba került: ezek poliglikolsavból (PGA), illetve polilaktid-kaprolaktonból készültek [19]. Az első, emberi idegen végzett allotranszplantációt (cadaverből nyert ideggel) 1878ban közölték. A beavatkozás végeredménye kilökődés volt, az immunoszuppresszív kezelés ellenére [20]. E kezelés hátrányai miatt számos szerző egyéb módszert használt, úgymint irradiációs kezelést, liofilizálást és különböző kémiai eljárásokat. Ez utóbbiak alkalmazása során decellularizációs eljárással eltávolították az allograftokból a myelint és a Schwann-sejteket, miközben a bazális lemezcső ép maradt [21, 22]. Ezek a kutatások eredményezték a kereskedelemben elérhető, decellularizált emberi allograftok kifejlesztését, amelyeket a klinikai gyakorlatban 2007 óta használnak [3].

A felszívódó idegvezetőket és a decellularizált allograftokat széles körben vizsgálták az érzőidegek helyreállítására, és megállapították, hogy a szenzoros regeneráció során kialakult érzőképesség jobb minőségben tért vissza, mint a primer ideg helyreállításánál vagy az idegtranszplantátum alkalmazásánál $[23,24]$. Az irodalmi adatok hiányosak az idegvezetók, illetve az allograftok (azonos speciesből nyert transzplantátumok) emberi felhasználásáról. A kevert (érző-mozgató) vagy a tisztán motoros idegek esetében fóképpen kazuisztikákat találhatunk e témakörből. Az utóbbi években több klinikai 
tanulmányban olvashattunk sikeres és sikertelen motoros reinnervációkról a felső végtagon, felszívódó idegvezető csövek alkalmazása után $[25,26]$. Ezek a nem egybecsengő eredmények korlátozhatják a módszer alkalmazását még a kisebb átmérőjű érzőidegek esetében is [27].

\section{Fontosabb irodalmi adatok}

\section{Nem felszivódó szintetikus idegvezetők}

S. Stanec és Z. Stanec [28] már 1998-ban politetrafluoroetilén csövet használt a medianus és az ulnaris idegek helyreállítására: 78,6\%-ban jó eredményt kaptak 1,5$4 \mathrm{~cm}$-es idegdefektus esetén, azonban, ha az idegcsonkok között ennél nagyobb távolság volt, csupán 13,3\%ban találtak sikeres reinnervációt. Később szilikongumiból készült csövet alkalmaztak Braga-Silva [29], valamint Lundborg és mtsai [30]. Lényegében a fenti szerzőhöz hasonló végeredményeket kaptak [3].

\section{Felszinódó szintetikus idegvezetők}

Ideg-helyreállítást 2007-ben a nervus accessorius idegsérülésnél két esetben végeztek [31]: az egyik betegnél felszívódó, Neurotube gyári elnevezésú (PGA) idegvezető csővel, a másiknál pedig autografttal. Az idegcsővel történt rekonstrukció után észrevehetően jobb volt az idegregeneráció mértéke. Más szerzőknél a Neurogen csövet használva figyelemreméltó eredmények születtek [32]. Az idegvégek közötti defektus egyik esetben sem haladta meg a $3 \mathrm{~cm}$-t [3]. Ugyanakkor a polilaktid-kaprolakton (Neurolac) idegvezetóvel Chiriac és mtsai egyértelmúen kedvezötlen végeredményeket értek el [33]. Az ulnaris és a medianus idegek helyreállítását ismertető másik prospektív klinikai tanulmány [34] azonban nem talált értékelhető különbségeket a kollagénalapú idegcsövek és a hagyományos, mikrosebészeti technikával végzett mütétek eredményei között.

\section{Allograftok}

Mackinnon és Hudson [35] 1992-ben közölték az eddigi leghosszabb, kevert idegsérülésnél alkalmazott allotranszplantátum-rekonstrukciót: $23 \mathrm{~cm}$-es hiányt pótoltak idegallografttal, emberi nervus ischiadicus sérülésénél; a mütét után immunoszuppressziós kezelést végeztek. 18 hónap után védő szenzibilitás kialakult, de a motoros reinnervációnak nem volt jele. Mackinnon későbbi közleményeiben [36, 37] a hosszú allograftokkal már kedvezőbb tapasztalatokról számolt be.

\section{Decellularizált ideg allotranszplantátumai}

Az ilyen típusú idegféleségek az Egyesült Államokban 2007-től álltak rendelkezésre a kereskedelmi forgalomban [3]. 2001 és 2012 között a közlemények többségé- ben a cadaverekből nyert graftokat az érzőidegek rekonstrukciójában használták fel. E transzplantátumokat (elsősorban az Amerikai Egyesült Államokban) donáció révén kapott friss tetemekből vették ki. A kezelés nélküli allograftokat használva azonban - az esetek többségében - immunválasz miatt kialakult rejectiót tapasztaltak. Hogy az immunológiai szövődményeket csökkentsék, a celluláris komponenseket eltávolították a graftokból. E célokra használtak irradiációt, detergens oldatokat (Sulfobetain-10, illetve TritonX-200/Sulfobetain-16; négy napig), liofilizálást, illetve egyszerü hưtést. Az egyik legnagyobb betegszámú (76 páciens) közleményben Brooks és mtsai [38] számoltak be az eljárással szerzett tapasztalataikról: sikeres reinnervációt az esetek 77\%ában találtak a kevert idegek és $86 \%$-ban a mozgatóidegek esetében.

Mások [39] liofilizált allograft átültetésének eredményeit hasonlították össze plexus brachialis vongálásos sérüléseiben a neurotizációs (idegáthelyezéses) mütétekkel: mindkét eljárás eredményeit hasonlónak találták. Megjegyzendő azonban, hogy nem mindegyik betegnél volt teljes fokú az idegsérülés [3].

\section{Megbeszélés}

Az elmúlt két évtized ideg-helyreállítással foglalkozó kísérletes és klinikai kutatásainak fontos eredménye az idegvezetôk kifejlesztése volt. Az irodalmi adatok áttekintése során megállapítható, hogy nehéz bizonyítékokon alapuló végleges következtetéseket levonni az idegvezető csövek nagyszámú változatai miatt. A kérdés elbírálását tovább nehezíti az idegrekonstrukciós eljárások különbözősége is; különösképpen a kevert funkciójú, illetve a mozgatóidegek eseteiben [3]. Összefoglalva a publikációk által közölt eredményeket, két fontos tényező jelenlétét szükséges hangsúlyozni: a reszekált idegvégek között létrejött defektus ne haladja meg a $6 \mathrm{~mm}$-t, továbbá a sérült idegek átmérője 3-7 mm között legyen. Ilyen esetekben a medianus és ulnaris idegeken jó idegregenerációra számíthatunk $[30,34]$.

Számos szerző tanulmányozta a tartósítási folyamaton átesett idegallograftokat [3]. A következtetések korántsem bizonyultak egyértelmünek, ezért szükségesnek látszik egy prospektív, randomizált értékelő tanulmány elkészítése, amely tisztázná a különböző eljárásokkal tartósított idegallograftok szerepét az autograftok ellenében mozgató- és kevert idegek esetében [40].

Az irodalmi adatok tanulmányozása során nyilvánvalóvá vált, hogy nincsen objektív mértékegység a kéz izomerejének értékelésére. Az e célra kidolgozott $M R C$ (Medical Research Council) -skála széles körben használatos, azonban számos gyenge pontja van. Az átdolgozott változatot is sokan használják, de intézetenként különböző módosításai vannak [41]. Mindezek miatt az eredmények nem tekinthetők egységesen összehasonlíthatóknak. Több tanulmányban nem következetes a reinnerváció idejének a megállapítása sem [3]. Más publikációkban 
pedig nem vették figyelembe a rendellenes beidegzéseket, például a Martin-Gruber-féle anasztomózisokat. Ezek nem mások, mint a kéz mozgatóbeidegzésében, a nervus medianus és a nervus ulnaris közötti idegi összeköttetések, motoros átfedések [42]. Bár az EMG-vizsgálatokat gyakran végzik el a reinnerváció ellenőrzésére, tudni kell, hogy az eljárás nem mindig jelzi a sikeres motoros beidegzés bekövetkeztét, ezért a módszert csak körültekintően lehet értékelni [3].

Ami a helyreállított idegsérülések prognózisát illeti, minél több idố telik el a sérüléstől az idegrekonstrukciós mútétig, annál rosszabb lesz a prognózis; fóképpen a proximalis idegsérülések esetében. Felnőtteknél, kevert típusú, illetve tisztán mozgatóidegek sérülése után egy évig, míg gyermekeknél több év után is sikeres lehet az ideg-helyreállító mútét. Érzőideg esetében ez az idő jóval több (akár 10[!] év is) lehet. A helyreállító idegmútétek után a legjobb eredmény a nervus radialis sérülésének rekonstrukcióját követően remélhetô, ezt követi a nervus medianus, a legrosszabb végeredmény pedig a nervus ulnaris sérülésének helyreállítása után várható [42].

\section{Következtetés}

A közölt - többségében kísérletes - irodalmi adatok értékelése során megállapítható, hogy úgy az idegvezetó csövek, mint az allograftok alkalmazásánál a szerzők nagyobb része jó eredményekről számolt be a mozgató- és a kevert idegek esetében, amikor a defektus kevesebb volt $6 \mathrm{~mm}$-nél, az idegátmérő pedig 3 és $7 \mathrm{~mm}$ között váltakozott. A nagyobb átmérôjú vagy nagyobb defektussal rendelkező idegsérüléseknél az autológ idegátültetést részesítették a szakemberek előnyben. Ha az alapvető tudományos irodalomra hagyatkozunk, a betegeknél a legtöbb tanulmányban az autológ transzplantátumok bizonyultak statisztikailag előnyösebbnek; ugyanakkor az állatkísérletes publikációkban sikeresebbnek mutatkoztak az allograftok és a kollagénalapú idegvezető csövek. A közeljövőben elvégzendő prospektív, randomizált közlemények lesznek hivatottak eldönteni az eljárások valódi értékeit a kézidegek defektussal járó sérüléseinek ellátásában.

Anyagi támogatás: A közlemény megírása anyagi támogatásban nem részesült.

A szerző a cikk végleges változatát elolvasta és jóváhagyta.

Érdekeltségek: A szerzőnek nincsenek érdekeltségei.

\section{Irodalom}

[1] Bíró V. Developments in the management of nerve injuries on the hand. Literary analysis and own experiences from the past forty years. $[\mathrm{Az}$ idegsérülések ellátásának fejlődése a kézen. Irodalmi elemzés és saját tapasztalatok az elmúlt negyven évról.]
Magyar Traumatológia, Ortopédia, Kézsebészet, Plasztikai Sebészet 2007; 5: 250-263. [Hungarian]

[2] Bíró V. The possibilities of using mesenchymal stem cells in the reconstruction of peripheral nerve injuries. [A mesenchymalis őssejtek felhasználásának lehetőségei a perifériás idegsérülések helyreállításában. Irodalmi áttekintés.] Magyar Traumatológia, Ortopédia, Kézsebészet, Plasztikai Sebészet 2010; 53: 236-245. [Hungarian]

[3] Rbia N, Shin AY. The role of nerve graft substitutes in motor and mixed motor/sensory peripheral nerve injuries. J Hand Surg Am. 2017; 42: 367-377.

[4] Bíró V. Advances in reconstructive options of nerve injuries in the hand. [A kezelési elvek fejlődése a kéz idegsérüléseinek helyreállításában.] Orv Hetil. 2012; 153: 1767-1778. [Hungarian]

[5] Bíró V. Thoughts on the factors that influence the outcome of the hand nerve injuries. [Gondolatok a kéz idegsérüléseinek végeredményét befolyásoló tényezőkrôl.] Magyar Traumatológia, Ortopédia, Kézsebészet, Plasztikai Sebészet 2015; 58: 8185. [Hungarian]

[6] Kós R. The surgery of the hand. [A kéz sebészete.] Medicina Könyvkiadó, Budapest, 1961. [Hungarian]

[7] Kovácsy Á. Investigation of the regeneration of injured nerves in the hand. Experimental and clinical researches. [A sérült ideg regenerációjának vizsgálata a kézen. Kísérletes és klinikai vizsgálatok. Kandidátusi értekezés.] Pécs, 1994. [Hungarian]

[8] Móricz O, Bíró V. New methods in the experimental reconstruction of the nerve defects. [Újabb módszerek az idegdefektusok kísérletes helyreállításában.] Magyar Traumatológia, Ortopédia, Kézsebészet, Plasztikai Sebészet 1994; 37: 447-449. [Hungarian]

[9] Renner A, Sántha E. The surgery of the hand. [A kéz sebészete.] KADIX Press, Budapest, 2014. [Hungarian]

[10] Renner A, Cserkuti F, Rutek Zs, et al. Late results of the nerve transplantations in the upper extremity and the hand. [Az idegtranszplantációk késői eredményei a felső végtagon és a kézen.] Magyar Traumatológia, Ortopédia, Kézsebészet, Plasztikai Sebészet 2014; 57: 81-83. [Hungarian]

[11] Simonka JA. Surgical management of peripheral plexus and nerve injury. In: Büki A, Szeifert Gy. (eds.) Baseline of neurotraumatology. [Perifériás plexus- és idegsérülések sebészi ellátása. In: Büki A, Szeifert Gy. (szerk.) A neurotraumatológia alapvonalai.] Semmelweis Kiadó, Budapest, 2014; pp. 282-289.

[12] Semionow M, Brzezicki G. Current techniques and concepts in peripheral nerve repair. Int Rev Neurobiol. 2009; 87: 141-172.

[13] Seidel J, Koenig R, Antoniadis G, et al. Surgical treatment of traumatic peroneal nerve lesions. Neurosurgery 2008; 62: 664673; discussion 664-673.

[14] Brushart TM. Preferential reinnervation of motor nerves by regenerating motor axons. J Neurosci. 1988; 8:1026-1031.

[15] Brushart TM. Motor axons preferentially reinnervate motor pathways. J Neurosci. 1993; 13: 2730-2738.

[16] Brushart TM, Seiler WA. Selective reinnervation of distal motor stumps by peripheral motor axons. Exp Neurol. 1987; 97: 289300.

[17] Belkas JS, Shoicet MS, Midha R. Peripheral nerve regeneration through guidance tubes. Neurol Res. 2004; 26: 151-160.

[18] Dellon AL, Mackinnon SE. An alternative to the classic nerve graft for the management of the short nerve gap. Plast Reconstr Surg. 1988; 82: 849-856.

[19] Wangensteen KJ, Kalliainen LK. Collagen tube conduits in peripheral nerve repair: a retrospective analysis. Hand (N.Y.) 2010; 5: 273-277.

[20] Albert E. Berichte des Naturwissenschaftlich-medizins in Innsbruck. Universitätsverlag Wagner, Innsbruck, Austria, 1878; p. 97.

[21] Hudson TW, Zawko S, Deister C, et al. Optimized acellular nerve graft is immunologically tolerated and supports regeneration. Tissue Eng. 2004; 10: 1641-1651. 
[22] Sondell M, Lundborg G, Kanje M. Regeneration of the rat sciatic nerve into allografts made acellular through chemical extraction. Brain Res. 1998; 795: 44-54.

[23] Bertleff MJ, Meek MF, Nicolai JP. A prospective clinical evaluation of biodegradable neurolac nerve guide for sensory repair in the hand. J Hand Surg Am. 2005; 30: 513-518.

[24] Taras JS, Amin N, Patel N, et al. Allograft reconstruction for digital nerve loss. J Hand Surg Am. 2013; 38: 1965-1971.

[25] Rosson GD, Williams EH, Dellon AL. Motor nerve regeneration across a conduit. Microsurgery 2009; 29: 107-114.

[26] Moore AM, Kasukurthi R, Magill CK, et al. Limitation of conduits in peripheral nerve repairs. Hand (N.Y.) 2009; 4: 180-186.

[27] Ray WZ, Mackinnon SE. Management of nerve gaps: autografts, allografts, nerve transfers, and end-to-side neurorrhaphy. Exp Neurol. 2010; 223: 77-85.

[28] Stanec S, Stanec Z. Reconstrucion of upper-extermity peripheral nerve injuries with ePTFE conduits. J Reconstr Microsurg. 1998; 14: 227-232.

[29] Braga-Silva J. The use of silicone-tubing in the late repair of the median and ulnar nerves in the forearm. J Hand Surg Br. 1999; 24: 703-706

[30] Lundborg G, Rosen B, Dahlin L, et al. Tubular repair of the median or ulnar nerve in the human forearm: a 5-year follow-up. J Hand Surg Br. 2004; 29: 100-107.

[31] Ducic I, Maloney CT Jr, Dellon AL. Reconstruction of the spinal accessory nerve with autograft or neurotube? Two case reports. J Rconstr Microsurg. 2005; 21: 29-33.

[32] Ashley WW Jr, Weatherly T, Park TS. Collagen nerve guides for surgical repair of brachial, plexus birth injury. J Neurosurg. 2006; 105(6 Suppl): 452-456.

[33] Chiriac S, Facca S, Diaconu M, et al. Experience of using the bioresorbable copolyester poly(DL-lactide- $\varepsilon$-caprolactone) nerve conduit guide Neurolac ${ }^{\mathrm{TM}}$ for nerve repair in peripheral nerve defects: report on a series of 28 lesions. J Hand Surg Eur Vol. 2012; 37: 342-349.
[34] Boekstyns ME, Sorensen AL, Vineta JF, et al. Collagen conduit versus microsurgical neurorrhaphy: 2-year follow-up of a prospective, blinded clinical and electrophysiological multicenter randomized, controlled trial. J Hand Surg Am. 2013; 38: 24052411.

[35] Mackinnon SE, Hudson AR. Clinical applicaton of peripheral nerve transplantation. Plast Reconstr Surg. 1992; 90: 695-699.

[36] Mackinnon SE. Nerve allotransplantation following severe tibial nerve injury. Case report. J Neurosurg. 1996; 84: 671-676.

[37] Mackinnon SE, Doolabh VB, Novak CB, et al. Clinical outcome following nerve allograft transplantation. Plast Reconstr Surg. 2001; 107: 1419-1429.

[38] Brooks DN, Weber RV, Chao JD, et al. Processed nerve allografts for peripheral nerve reconstruction: a multicenter study of utilization and outcomes in sensory, mixed and motor nerve reconstructions. Microsurgery 2012; 32: 1-14.

[39] Squintani G, Bonetti B, Paolin A, et al. Nerve regeneration across cryopreserved allografts from cadaveric donors: a novel approach for peripheral nerve reconstruction. J Neurosurg. 2013; 119: 907-913.

[40] Shahgoli L, Bengtson KA, Bishop AT, et al. A comparison of manual and quantitative elbow strenght testing. Am J Phys Med Rehabil. 2012; 91: 856-862.

[41] MacAvoy MC, Green DP. Critical reappraisal of Medical Research Council muscle testing for elbow flexion. J Hand Surg Am. 2007; 32: 149-153.

[42] Bíró V, Nyárády J. Hand injuries. Illustrated pocket book for emergency care. [Kézsérülések ügyeletben. A sürgősségi ellátás képes zsebkönyve.] Medicina Könyvkiadó, Budapest, 2013.

(Bíró Vilmos dr., Pécs, Hajnóczy u. 25/A, II. em. 2., 7633 e-mail: biro.vilmos $2 @$ chello.hu)

\section{"Non omnia possumus omnes." (Vergilius) (Nem mindnyájan vagyunk képesek mindenre.)}

